\title{
Comparative study of macrofungi in different patches of Boshan Community Forest in Kathmandu, Central Nepal
}

\author{
Bhawani Bhandari and Sanjay Kumar Jha* \\ Central Department of Botany, Tribhuvan University, Kathmandu, Nepal
}

\begin{abstract}
Macrofungi are considered as a group of high-value forest resources worldwide. In this paper, we report species richness and composition of macrofungi in three different forest patches (Schima-Castanopsis, Pinus and Alnus forest) of mid-hill, central Nepal, which were managed under Boshan Community Forest. A Systematic random sampling was applied where 20 rectangular plots of size $10 \mathrm{~m} \times 10 \mathrm{~m}$ were laid at $1500 \mathrm{~m}$ to $1600 \mathrm{~m}$ elevation in each forest type. Species richness and composition of macrofungi were accessed in each forest type. Schima-Castanopsis forest was the richest in terms of macrofungal diversity (70 species), followed by Alnus forest (64) and Pinus forest (56). Polyporaceae was the largest family, followed by Amanitaceae. Agaricales (Rusulla and Amanita) were dominant in Schima-wallichi and Alnus forests, whereas Boletales were dominant in Pine forest. Macrofungal species richness increased with increasing canopy, soil moisture and soil pH. The species richness, however, had weak relationships with litter cover and disturbance. Based on the present study it can be concluded that the study area is rich in macrofungal diversity. Moist soil followed by litter and decaying wood assist the higher diversity of macrofungi. Species diversity is higher in moist and dense canopy forests (like, Schima-Castanopsis and alder) than in open and dry pine forest. Soil moisture, soil pH and tree canopy cover are the most important variables affecting macrofungal diversity.
\end{abstract}

Key-words: community forest, fungal diversity, mid-hill, species richness.

\section{Introduction}

Conservation of biodiversity depends on reliable information about the kinds of organism present, total number of species in each of these group, their genetic diversity, their habitats, distribution pattern, ecology, population size, evolutionary history, and their trends both in time and space. In practice, surveys are targeted towards organism groups that are generally considered spectacular, cute and intelligent. Fungi are one among them, diversity study of which is masked by higher plants and organisms. Thus, macro- and micro-fungi are highly underrepresented in the conservation literature (Heilmann and Vesterholt 2008), but they equally hold large genetic diversity with their potential implication in nature and human welfare.

Macrofungi are a group of fungi which produce mature spore-bearing and morphologically distinct fruiting bodies, which are visible to the unaided eye (Arnolds 1992). They are known to inhabit diverse types of habitat varying in the composition of their tree species and substrates. These habitats have assemblages of varied macrofungal species, some of which are very specific and are facilitated by the presence of trees and other plant species, which provide a functional platform to the fungi (Unterseher and Tal 2006). However, there are some macrofungi that are neutral to the presence or absence of dominant tree species in particular habitat type
(Zhang and Zak 1998). Studies on the specificity of macrofungi in different habitats with higher plants date back to the past century, and since then many qualitative features of such preferences have been observed and analyzed (Arnolds 1992), but how does the aboveground plant diversity correlate with the understory or belowground macrofungal diversity is still a matter of study. It has been well known that macrofungi are the important aspects of the forest ecosystem and biodiversity.

Usually fleshy macrofungi flourish in humid months of the year, whereas shelves fungi, cup fungi or simply dry mushrooms are abundant in dry months too. However, variations in microclimatic condition govern their occurrence, abundance and diversity in particular condition (Kustszegi et al. 2015). O'Hanlon and Harrington (2012) stated that compositions of aboveground vegetation also determine the macrofungal diversity. The suitable condition for the occurrence of massive production of carpophores depends upon the humidity, nutritional substrate and the mild atmospheric temperature (Dickinson and Lucas 1979).

The macrofungal species composition and diversity vary with nutrient (particularly nitrogen), moisture, forest type and disturbance (Trudell and Edmonds 2004; Christensen and Heilmann-Clausen 2009; López-Quintero et al. 2012; O'Hanlon and Harrington 2012; Pradhan et al. 2013). Climatic conditions as well as phyto-geomorphologic features affect

*Corresponding author: e-mail - sk.jha@cdbtu.edu.np 
macrofungal fructiûcation (Brunner et al. 1992). More information is available on composition and diversity of vascular plants in different forests but ecological study of macrofungi is non-existent except a few studies from West Bengal, India (Pradhan et al. 2013; Baral et al. 2015). In this paper, we report the effect of forest stand characteristics and environmental factors on macrofungal species composition and richness in mid-hill region, central Nepal.

\section{Materials and methods}

RESEARCH SITE

The study was carried out in three different forest patches within Boshan Community Forest in mid-hill region of Kathmandu district, central Nepal (Figure 1). The study was conducted from an elevation of $1500 \mathrm{~m}$ to $1600 \mathrm{~m}$ above sea level (asl). Meteorological data of the period 2006-2015 obtained from Department of Hydrology and Meteorology, Government of Nepal revealed that the study area is represented by subtropical climate and receives an average of $1488 \mathrm{~mm}$ annual rainfall with maximum monthly rainfall of $375 \mathrm{~mm}$ occurring during July. The monthly mean temperature is maximum in June $\left(30.27^{\circ} \mathrm{C}\right)$ and minimum in January $\left(2.97^{\circ} \mathrm{C}\right)$.

\section{STUDY DESIGN}

The Boshan Community Forest (BCF) was selected as it has different forest types almost at the same elevation. Three forest types were selected: Schima wallichii-Castanopsis tribuloides (hereinafter referred to as Schima-Castanopsis forest), Alnus nepalensis (Alnus forest) and Pinus roxburghii (pine forest). During preliminary field surveys (in March 2016), elevation of all the three forest types within BCF was obtained using a portable altimeter (and verified with a GPS devise) with the help of BCF user group members. In each forest type, rectangular plots each of $10 \mathrm{~m} \times 10 \mathrm{~m}$ size were established. The numbers of plot to be sampled were determined on the basis of spatial area of each forest.

\section{FIELD SAMPLING}

A detailed sampling of macrofungi diversity was made by applying systematic random method during June/July 2016, where plots were laid in each forest type with a minimal variation in elevation (1500-1600 m asl). A total of 20 plots were laid in each forest types along four transects, maintaining inter-plot distance of at least $20 \mathrm{~m}$ (Baral et al. 2015).

Presence/absence data of macrofungal species was recorded in each plot. Bio-physical variables, such as tree canopy cover, litter cover and anthropogenic disturbances

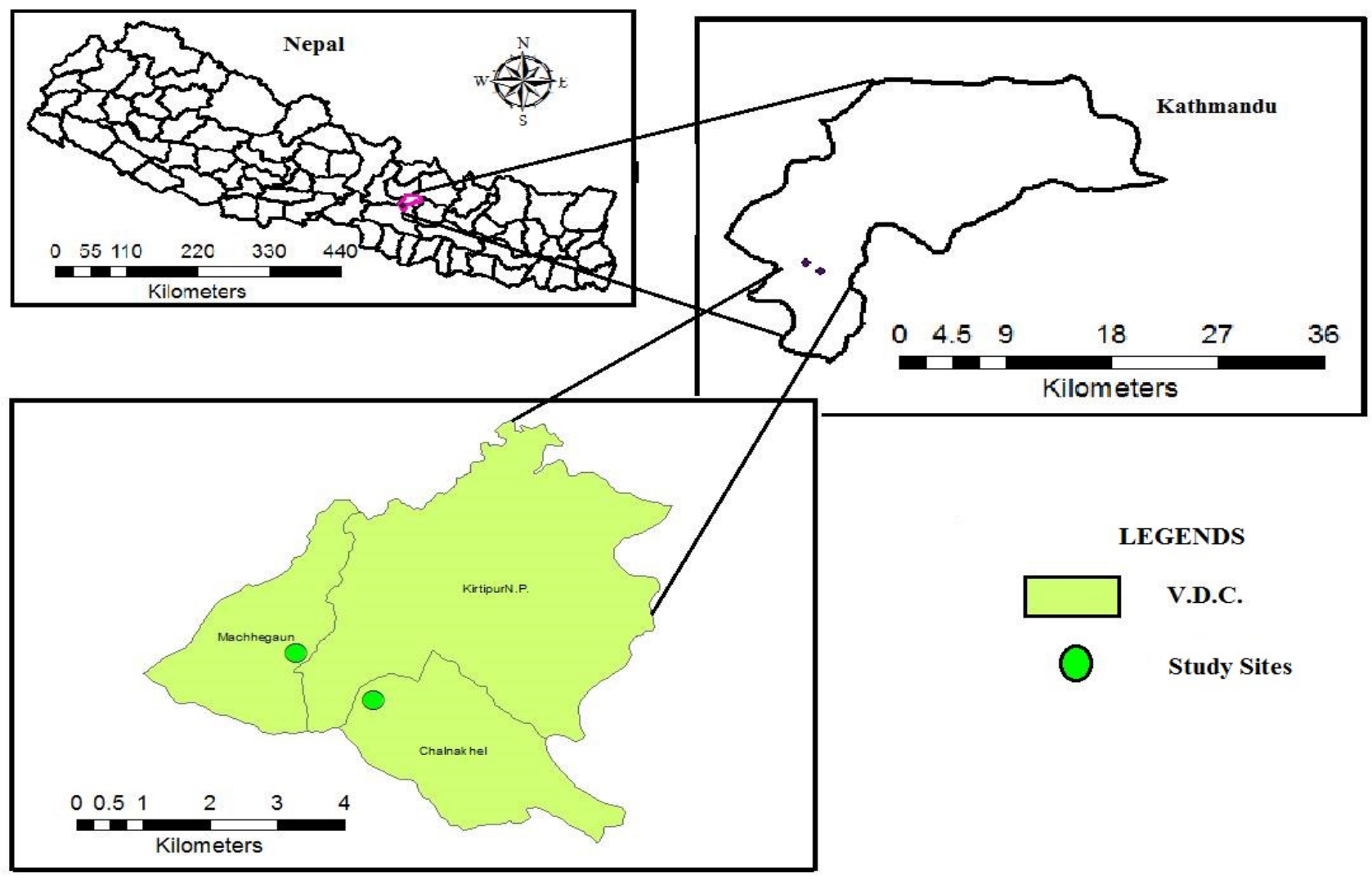

Figure 1. Location map of study area, showing position of Kathmandu district in Nepal: Village Development Committees (VDCs) in district and studied forest in VDCs. 
(trampling, grazing and fire) were recorded in each plot. Tree canopy cover and litter cover (in percentage) were estimated visually. For tree canopy cover, observation was made from the middle of each plot. Slope was measured with the help of a clinometer. Soil samples were collected at a depth of $15 \mathrm{~cm}$ from four corners and at the middle of each plot using a soil digger. The samples from each plot were mixed thoroughly and from the mixture about $200 \mathrm{~g}$ was taken in zipper polythene bag. The samples were air dried in shade for a week and stored in air tight plastic bags until laboratory analysis. Soil pH and moisture were determined following Zobel et al. (1987).

Macrofungi were identified in situ where possible. Many of the unidentified specimens were preserved (dry and in liquid) and compared with the specimen at National Herbarium (KATH) and Tribhuvan University Central Herbarium (TUCH). Collected samples were studied on the basis of their morphological characters with the help of Myco-key (http:/ www.mycokey.com, www.mushroomexpert.com, www. mycoweb.com, www.mushroomobserver.org), and Index Fungorum (http://www.indexfungorum. org/Names/ Names. asp). Standard identification manual (Marshal 1901; Adhikari 2000; Kumar et al. 1990) were also followed for mushroom identification along with the expert consultations.

\section{DATA ANALYSIS}

Field data were firstly checked for normality and homogeneity of variance in SPSS Version 20. Macrofungal species richness is defined as the number of infrageneric taxa per plot. Relationships between environmental variables (canopy, soil $\mathrm{pH}$, soil moisture, litter cover and disturbance) and macrofungal species richness were assessed though Pearson correlation analysis. In addition, linear regression was performed in SPSS Version 20 to see the effect of tree canopy, soil moisture and soil $\mathrm{pH}$ on macrofungal species richness.

\section{Results}

\section{SPECIES RICHNESS AND COMPOSITION}

A total of 85 macrofungal taxa were documented, of which 52 were identified up to species level and 24 to generic level. Nine taxa remained unidentified due to immature/over-mature stage. Of the total identified macrofungal (genetic and infrageneric) taxa, 8 belonged to Ascomycota and 68 to Basidiomycota. The identified macrofungi belonged to 26 families. Polyporaceae was the largest family, consisting of 9 species. Amanitaceae and Boletaceae, with 8 species each, represented the second largest families, followed by Agaricaceae and Russulaceae, having 7 and 6 species respectively (Figure 2).
Schima-Castanopsis forest harbored highest macrofungal diversity (total 70 species) in all three substrates studied (Figure 3), followed by Alnus forest (64 species) and pine forest (56 species). Agaricales (Rusulla and Amanita) were dominant in Schima-wallichi and Alnus forests, whereas Boletales were dominant in pine forest. As compared to litter and wood, soil was the most important substrate for maintaining macrofungal diversity in all three forest types (Figure 3 ).

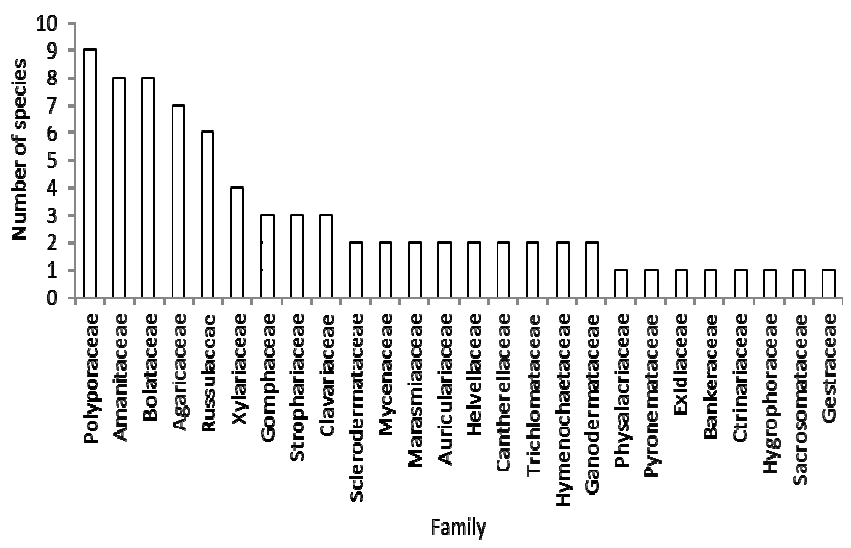

Figure 2. Number of macrofungal species found in study area belonging to their respective families.

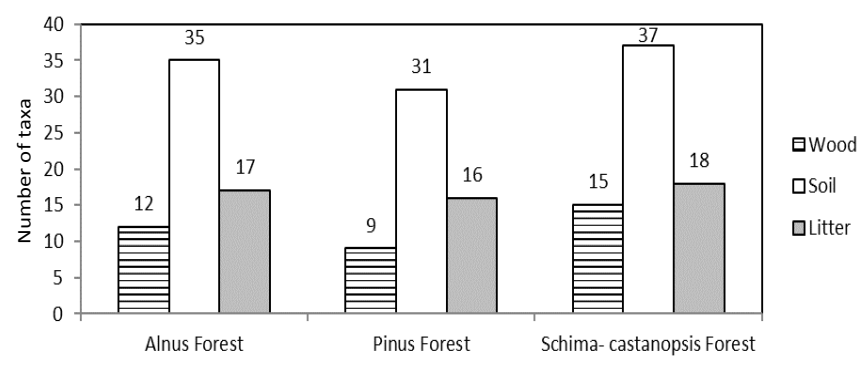

Figure 3. Distribution of macrofungi on the basis of habitat in different forest.

\section{RELATIONSHIPS OF SPECIES RICHNESS WITH ENVIRONMENTAL VARIABLES}

Soil $\mathrm{pH}$, soil moisture, tree canopy and litter cover varied from 5.5 to $6.3,21.0$ to $47.7 \%, 25$ to $98 \%$, and 45 to $90 \%$, respectively. Among the environmental variables compared, tree canopy cover, soil $\mathrm{pH}$ and soil moisture had the most signiûcant positive relationships with macrofungal species richness (Table 2, Figure 4). Species richness increased with increasing tree canopy, soil $\mathrm{pH}$ and soil moisture (Figure 4). Macrofungal species richness showed weak positive relationship with litter cover. Disturbance was negatively correlated with macrofungal species richness, but the result was statistically insignificant (Table 2). 
Table 2. Pearson's correlation between environmental variables and species richness of macrofungi.

\begin{tabular}{llllll}
\hline & Soil $\mathbf{~ p H}$ & Soil moisture & Litter coverage & Tree canopy coverage & Disturbance \\
\hline Species richness & $0.528^{* *}$ & $0.598^{* *}$ & 0.028 & $0.523^{* *}$ & -0.061 \\
\hline${ }^{*}$ Crrelation
\end{tabular}

${ }^{*}$ Correlation is significant at $p=0.05$ level; ${ }^{* *}$ correlation is significant at $p=0.01$ level.
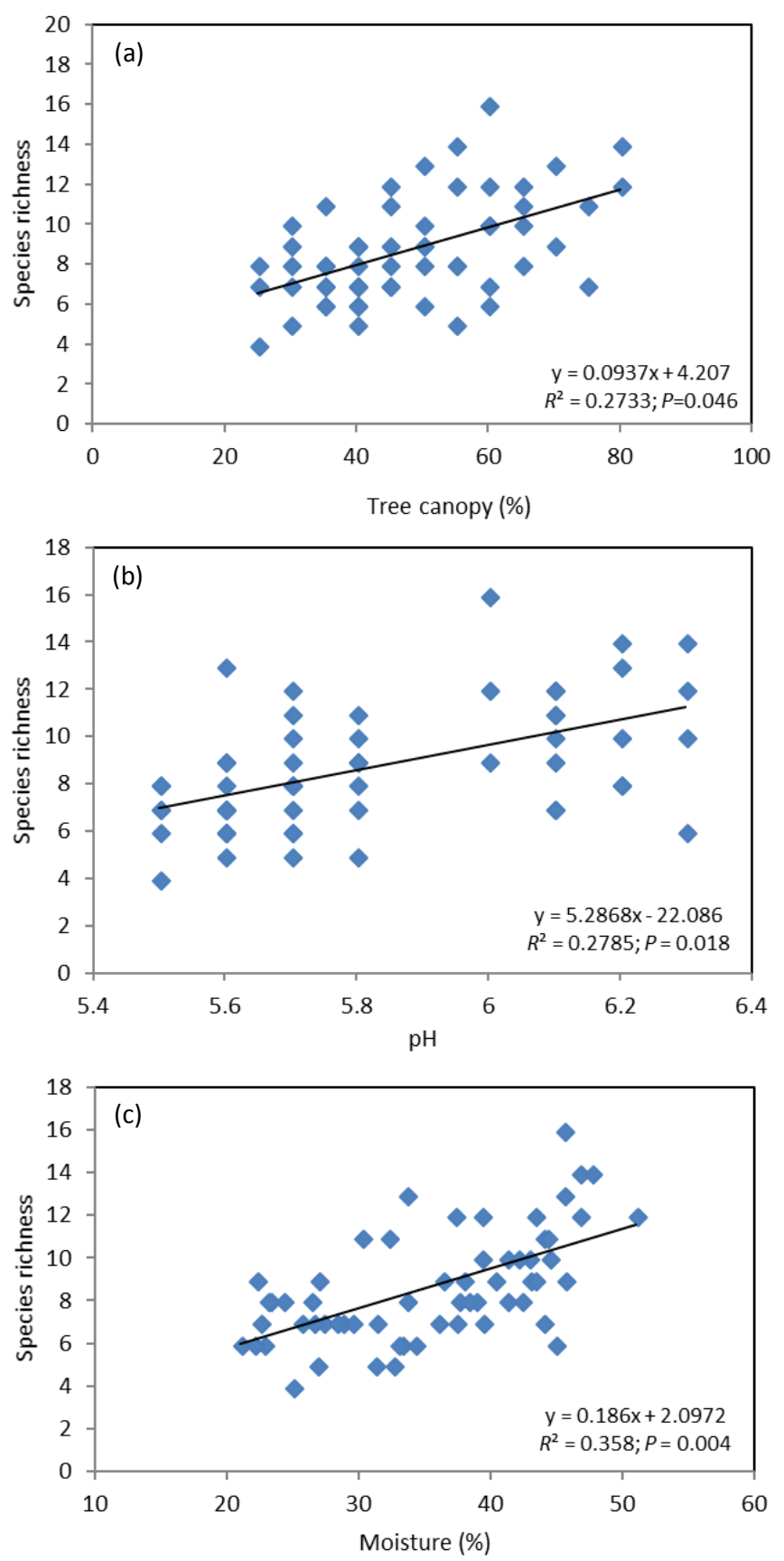

Figure 4. Variation in species richness of macrofungi with (a) tree canopy, (b) soil $\mathrm{pH}$ and (c) soil moisture.

\section{Discussion}

\section{MACROFUNGAL RICHNESS AND COMPOSITION}

The present study has shown that the forest dominated by Schima-Castanopsis had the highest macrofungal species richness compared to Alnus and pine forests. Of the total macrofungal taxa collected (85), highest proportion (82.35\%) of taxa was contributed by Schima-Castanopsis forest, followed by Alnus (75.29\%) and pine forest (65.88\%). The high macrofungal diversity in broad-leaved SchimaCastanopsis forest is mainly related to high soil moisture and greater cover of tree species. Alnus forest mostly occupy rocky and landslide areas with comparatively less suitable substrate than Schima-Castanopsis forest for macrofungal growth. Pine forests usually show comparatively dryness of habitat condition with low soil $\mathrm{pH}$ as pine litter have a tendency to acidify the soils (Pandey et al. 1995) and this might be the reason why the latter forest type harbored lowest macrofungal diversity among the three forest types compared. Macrofungi were recorded on different substrates, especially on soil, litter and wood. The finding of the study agrees with that conducted in India where macrofungi were reported in various habitats, like wood, litter and moist soil, among others (Nagaraju et al. 2014). As compared to litter and wood, soil was the most important substrate for maintaining macrofungal diversity in all three forest types studied. Higher number of macrofungi recorded in the present study on moist soil compared to litter and decaying wood is in agreement with previous study (e.g., Osti 2015). In a community forest in Gorkha, Nepal, Osti (2015) documented $52 \%$ of the total macrofungi from forest soil. Higher species diversity in Basidiomycota compared to Ascomycota (the ratio of Ascomycota to Basidiomycota in terms of species composition being 1:8.5) is probably contributed by higher number of mycorrhizal species found on soil as studies have shown that soil moisture and decaying litter facilitate much diverse macrofungi (Mueller 2007).

\section{MACROFUNGAL RICHNESS IN RELATION TO ENVIRONMENTAL VARIABLES}

Fungal diversity is closely related to forest structure and composition (Richard et al. 2004). In the present study, macrofungi varies with the forest types. The existence of distinctive macrofungal communities related to the dominant tree species of the forest have been confirmed by many other studies (Straatsma and Krisai-Greilhuber 2003; Gates et al. 2011; O'Hanlon and Harrington 2011). The formation of specific communities of macrofungi in the present study may be due to host preferences which is similar to the findings of Bills et al. (1986), and O'Hanlon and Harrington (2011).

Canopy is another important environmental factor for fungal diversity. Present study revealed highest macrofungal diversity in canopy-rich forests, which coincides with the 
observation made by Baral et al. (2015) in central Nepal. Sysouphanthong et al. (2010) also reported higher macrofungal diversity in forests having higher canopy closure.

Yamanaka (2005) found that many of the saprophytic species of fungi grew well at $\mathrm{pH} 7$ or 8 and the ectomycorrhizal species showed optimum growth at $\mathrm{pH} 5$ or 6 . Most species of saprobic fungi consist of wood- and dung-inhabiting species; whereas, the species inhabiting on soil was high in this research (Figure 4). The $\mathrm{pH}$ range was found to be 5-6 in most of the plots, so it can be said that $\mathrm{pH}$ is the key factor in determining soil fungal community composition. Zang et al. (2016) suggest that the $\mathrm{pH}$ range of 5 to 6 favors the growth of soil fungi.

The moisture is one of the major environmental factors influencing fruiting in macrofungi. Generally, small-sized species are delicate and fragile with small wiry stipe (Trudell and Edmonds 2004; Christensen and Heilmann-Clausen 2009). Species such as Coprinus, Marasmius and Mycena were found frequently in Alnus and Schima-Castanopsis forests than in pine forest. These species appeared and disappeared very quickly while the large sized fruit bodies fruited latter a continued period of more than two weeks. This might be due to their small fruiting body and their nature of forming fruiting body at relatively shallow depth thus change of moisture has more effect on them than other group of fungi.

\section{Conclusions}

Based on the present study it can be concluded that the study area is rich in macrofungal diversity with species richest families being the Polyporaceae, followed by Amanitaceae, Boletaceae, Agaricaceae and Russulaceae. Moist soil followed by litter and decaying wood assist the higher diversity of macrofungi. Species diversity is higher in moist and dense canopy forests (like, Schima-Castanopsis and alder) than in open and dry pine forest. Soil moisture, soil $\mathrm{pH}$ and tree canopy cover are the most important variables affecting macrofungal diversity.

\section{Acknowledgements}

We acknowledge the support of Dr. Lal B Thapa, Boshan Communiity Forest members and local inhabitants. Sujan Balami and Hari Sharan Adhikari helped during ûeld work. The information provided by Sambhu Ram Bista, and ofûcials of Ilaka Ban Ofûce, Kirtipur, had been crucial for the field work. We also thank Mr. Siva Devkota for his help in the identification of macrofungi. Finally, we thank anonymous reviewers and editor for their valuable comments and suggestions on the earlier versions of the manuscript.

\section{References}

Adhikari M.K. 2000. Mushrooms of Nepal. Buddha Academic Publishers, Kathmandu, Nepal.

Arnolds E. 1992. The analysis and classification of fungal communities with special reference to macrofungi. In: Fungi in Vegetation (W. Winterhoff, ed.), pp. 7-47. Kluwer Academic Publishers Dordrecht.

Baral S., Thapa-Magar K.B., Karki G., Devkota S. and Shrestha B.B. 2015. Macrofungal diversity in community-managed Sal (Shorea robusta) forests in central Nepal. Mycology, 6: 151-157.

Bills G.F., Holtzman G.I. and Miller Jr, O.K. 1986. Comparison of ectomycorrhizal-basidiomycete communities in red spruce versus northern hardwood forests of West Virginia. Canadian Journal of Botany, 64: 760-768.

Brunner I., Brunner F. and Laursen G.A. 1992. Characterization and comparison of macrofungal communities in an Alnus tenuifolia and an Alnus crispa forest in Alaska. Canadian Journal of Botany, 70: 1247-1258.

Christensen M. and Heilmann-Clausen J. 2009. Forest biodiversity gradients and the human impact in Annapurna Conservation Area, Nepal. Biodiversity and Conservation, 18: 2205-2221.

Dickinson C.H. and Lucas J.A., eds. 1979. The Encyclopedia of Mushrooms. GP Putnam's Sons, New York, USA.

Gates G.M., Mohammed C., Wardlaw T., Ratkowsky D.A. and Davidson N.J. 2011. The ecology and diversity of woodinhabiting macrofungi in a native Eucalyptus obliqua forest of southern Tasmania, Australia. Fungal Ecology, 4: 56-67.

Heilmann C.J. and Vesterholt J. 2008. Conservation: selection criteria and approaches. In: Ecology of Saprophytic Basidiomycetes (L. Boddy, J. Frankland and W.P. van, eds.), pp. 325-347. Elsevier, Amsterdam, The Netherlands.

Kumar A., Bhatt R.P. and Lakhanpal T.N. 1990. Amanitaceae of India. Bishen Singh Mahendra Pal Singh, Dehradun, India.

Kustszegi G., Siller I., Dima B., Takacs K., Merenyi Z., Varga T., Turcsanyi G., Bidlo A. and Odor P. 2015. Drivers of macrofungal species composition in temperate forests, West Hungary: functional groups compared. Fungal Ecology, 17: 69-83.

López-Quintero C.A., Straatsma G., Franco-Molano A.E. and Boekhout T. 2012. Macrofungal diversity in Colombian Amazon forests varies with regions and regimes of disturbance. Biodiversity and Conservation, 21: 2221-2243.

Marshall N.L. 1901. The Mushroom Book. New York Botanical Garden, New York, USA.

Mueller G.M. and Schmit J.P. 2007. Fungal biodiversity: what do we know? What can we predict? Biodiversity and Conservation, 16 : $1-5$.

Nagaraju D., Kumar S.G, Kunwar I.K. and Manoharachary C. 2014. Fungi occurring on diversified habitats around some sanctuaries and water-bodies of Telangana and Andhra Pradesh, India. Journal of Experimental Biology, 2: 5 [online] URL: http:// www.jebas.org/00200520102014/Nagaraju\%20et\%20a1\%20 JEBAS.pdf.

O'Hanlon R. and Harrington T.J. 2011. Diversity and distribution of mushroom-forming fungi (Agaricomycetes) in Ireland. In: Biology and Environment: Proceedings of the Royal Irish Academy, pp. 117-133. Royal Irish Academy, Dublin, Ireland.

O'Hanlon R. and Harrington T.J. 2012. Macrofungal diversity and ecology in four Irish forest types. Fungal Ecology, 5: 499-508. 
Osti U. 2015. Study of Macrofungi in Community Forest of Dhawa Gorkha and Nutritional Value Analysis of Some Dominant Species. M.Sc. Dissertation. Central Department of Botany, Tribhuvan University, Kirtipur, Kathmandu, Nepal.

Pandey S.P., Tamang D.B. and Baidya S.N. 1995. Soil fertility management and agricultural production issues with reference to the middle mountain regions of Nepal. In: Challenges in Mountain Resource Management in Nepal: Processes, Trends and Dynamics in Middle Mountain Watersheds (H. Schreier, S. Brown and P.B. Shah, eds.), pp. 41-49. International Center for Integrated Mountain Development (ICIMOD), Kathmandu, Nepal.

Pradhan B. 2013. A comparative study on the predictive ability of the decision tree, support vector machine and neuro-fuzzy models in landslide susceptibility mapping using GIS. Computers and Geosciences, 51: 350-365.

Straatsma G. and Krisai-Greilhuber I. 2003. Assemblage structure, species richness, abundance, and distribution of fungal fruit bodies in a seven-year plot-based survey near Vienna. Mycological Research, 107: 632-640.

Sysouphanthong P., Thongkantha S., Zhao R., Soytong K. and Hyde K.D. 2010. Mushroom diversity in sustainable shade tea forest and the effect of fire damage. Biodiversity and Conservation, 19: 1401-1415.
Trudell S.A. and Edmonds R.L. 2004. Macrofungus communities correlate with moisture and nitrogen abundance in two oldgrowth conifer forests, Olympic National Park, Washington, USA. Canadian Journal of Botany, 82: 781-800.

Unterseher M. and Tal O. 2006. Influence of small scale conditions on the diversity of wood decay fungi in a temperate, mixed deciduous forest canopy. Mycological Research, 110: 169-178.

Yamanaka K. 2005. Cultivation of new mushroom species in East Asia. In: Mushroom Biology and Mushroom Products: Proceedings of the Fifth International Conference on Mushroom Biology and Mushroom Products, 8-12 April 2005, Shanghai, China (Q. Tan, ed.), pp 343-349. Edible Fungi Institute, Shanghai, China.

Zhang T., Wang N.-F., Liu H.-Y., Zhang Y.-Q. and Yu L.-Y. 2016. Soil $\mathrm{pH}$ is a key determinant of soil fungal community composition in the Ny-Ålesund Region, Svalbard (High Arctic). Frontiers in Microbiology, 7: 227. [online] URL: https://www.ncbi. nlm.nih.gov/pmc/articles/PMC4767930/ (doi: 10.3389/ fmicb.2016.00227).

Zhang Q. and Zak J. 1998. Potential physiological activities of fungi and bacteria in relation to plant litter decomposition along a gap size gradient in a natural subtropical forest. Microbial Ecology, 35: $172-179$.

Zobel D.B., Jha P.K., Behan M.J. and Yadav U.K.R. 1987. A Practical Manual for Ecology. Ratna Book Distributors, Kathmandu, Nepal. 